\title{
An Application of Mixture Oil of Syzygium Aromaticum(Clove) and Anethum Graveolens (Dill or Sowa) As An Alternative of Salphos For Food Seed Storage of Chickpea
}

\author{
Dr.Narendra Kumar ( $\sim$ narendra.microbiology@rediffmail.com ) \\ AMITY UNIVERSITY HARYANA MANESAR-122413,GURGAON,HARYANA,INDIA \\ PROF SM PAUL KHURANA \\ AMITY UNIVERSITY HARYANA MANESAR-122413,GURGAON,HARYANA,INDIA \\ VN PANDEY \\ Deen Dayal Upadhyay Gorakhpur University
}

\section{Research Article}

Keywords: Syzygium aromaticum, Anethum graveolens)Aspergillus flavus, A.niger, Fusariumoxysporum, MIC, shelf life of chickpea seed

Posted Date: February 15th, 2021

DOI: https://doi.org/10.21203/rs.3.rs-182116/v1

License: (c) (7) This work is licensed under a Creative Commons Attribution 4.0 International License. Read Full License 


\section{Abstract}

Mycological investigations of 25 seed samples of stored chick pea (Cicer arietinum L.) from grocery stores of Gurgaon and Gorakhpur revealed occurrence of seventeen fungal species belonging to genus viz., Alternaria , Aspergillus, Chaetomium, Colletotrichum, Curvularia,

Fusarium,Penicillium,Rhizopus,Rhizoctonia, and Sclerotium. In these Aspergillus flavus, A. niger, Fusarium oxysporum had dominance in terms of per cent occurrence. Only one species of Bruchid (Callosobruchus chinensis $\mathrm{L}$ ) occurred in all the 25 samples. The biodeterioration of seeds inoculated with fungi : A. flavus, A. niger, F.oxysporum and the insect - C. chinensis, revealed their role in seed deterioration. For chickpea food seed protection essential oils were extracted from edible commodity(Lavang(clove bud) and sowa leaf). Lavang oil registered highest antifungal activity inhibiting (100\%) mycelial growth of fungi, viz. species Aspergillus flavus, A. niger,Fusarium oxysporum at 300ppm but was fungicidal at $400 \mathrm{ppm}$. Sowa oil showed complete inhibition at 400ppm and was fungicidal at 500ppm. While mixture of both the oils showed complete inhibition (100\%) and fungicidal action at $400 \mathrm{ppm}$ against the dominant fungi. The oils showed $100 \%$ insect repellent activity and were found fungicidal at $0.02 \mathrm{ml}$ dose and also insecticidal. The mixture of oils was cidal at $0.02 \mathrm{ml}$ dose.

The mixture of oils showed a broad antifungal spectrum at 500ppm while only 70-93\% inhibitory activity at 300ppm. The oils' mixture's activity was not affected by temp,storage and autoclaving up to 150 days. Oils physico-chemical properties were studied. GC-MS analysis of Lavang oil depicted major components: 75.63 \%eugenol

while sowa leaf oil had $25.14 \%$ apiole. Formulation of Mixture of oils was more effective showing complete seed protection i.e.no growth of fungi and insects upto 150 days storage than salphos (150 days). While salphos controlled only maximum three fungi (A.terreus,C.dematium,F.moniliforme).The formulated oils mixture did not have any adverse effect on the chickpea seeds and increased their shelf life.

\section{Introduction}

The chickpea or chick pea (Cicer arietinum) is the most important and versatile legume,from Fabaceae,subfamilyFaboideae. It is locally known as gram or Bengal gram or garbanzo.This has highnutritional value. Dried chickpea seeds have $61 \%$ carbohydrate, $(17-22 \%)$ proteins and $6 \%$ fat by weight.It is one of the earliest cultivated legumes.Its history is 7500-year-old, as the remains have been found in theMiddle East. Chickpea is a key ingredient in hummus and chana masala. This is ground into flour to makefalafel. It is also used in salads, soups and stews, curry and other food items like roasted/baked channa. .

Chick pea is typically stored for six to eight months after harvest.But more than $90 \%$ of farmers donot take any precautions to protect it. Its proper storage enables farmers to earn high profit margins. Most farmers sell their chick pea seeds in village/local and urban markets. Aprox. 20$30 \%$ of the stored chick pea food seeds get deteriorated by fungi and insects. Thenon scientific storage of chick pea in rural areas leads to heavy losses of chickpea by fungi and insects. But detailed studies on such deterioration of stored chickpea food seeds have not been made so far. The chickpea seeds in the storage condition become more susceptible to fungal infection resulting in the lowering in seed germination and deterioration in storage. A damaged seedsproduce abnormal seedlings. Thus farmers are adviced to use pathogen free healthy seeds to overcome the losses in productivity. But without testing for seed health, it is not possible to detect \% healthy seeds to ensure better productivity.

A seed borne pathogen whether present internally or externally or associated with the seed as contaminant may result seed rot,seed necrosis, seed abortion, reduction or elimination of germination capacity thereby affecting of seed quality. This also causes seedling damage which produce crop diseases at later stages of plant growth through local or systemic infection ${ }^{1}$. Thebase of total food grain production in a country depends much on quality of the seeds. Seed health has an important role in successful cultivation and yield exploitation of a crop species.Some synthetic fungitoxic chemicals are used to control mycotoxin producing fungal infection but they also have their side effects ${ }^{2-3}$.

The synthetic preservatives because of carcinogenic effects are getting lesser preference so alternate for farmers is to shift on aromatic plants having of essential oil which have potent pesticidal potential.So potential of mixture essential oils is the need of time as single oil is not enough to protect pests.So if Exploiting synergies of several compounds may be a solution to handle this problem. But little is known on interactions that leads to additive,synergistic or even antagonistic effects ${ }^{4}$.

Lavang botanically known as Syzygium aromaticum $L$ are flower buds of aromatic nature. This have large leaves bearing of crimson flowers can be grouped in terminal clusters. This reaches up to 8-12meters. Flower buds initially looks a pale hue turning gradually in green, then to bright red when ready for harvest. Chemically Clove have eugenol ,eugenyl acetate , caryophyllene a-humulene, $\beta$-elemene,ledol and $a$-cadinene ${ }^{5}$.

Dill botanically called as Anethum graveolens $\mathrm{L}$ locally known as sowais. This is an annual herb used as vegetable belongs to celery family Apiaceaeused. This grows up to $40-60 \mathrm{~cm}$ having of slender hollow stems. Entire herb including stem, leaf and fruit are may be considered for flavoring of food and beverages. Used in cosmetics and in various medicinal preparations. This have antimicrobial, anti-oxidative and antispasmodic activities ${ }^{6,7}$.Sowa leaf contains o-cymene, apiole, a-thujene, exo-2-hydroxycineol , limonene, $\beta$-phellandrene dithydroumbellulone and 3-isoproyl-4-methyl-1-pentyn-3-ol myristicine ${ }^{8}$. 
So mycological analysis of stored chickpea food seeds were conducted in order to find out thedominant fungal species and insects responsible for its biodeterioration. The essential oil extracted from Lavang and sowa leaf locally available was evaluated for its fugitoxicity and repellent activity.Its chemical analysis were done.Experiments conducted for its MIC,nature, spectrum and storage. The efficacy of mixed oils(Lavang and sowa leaf)was compared with commercial pesticides Salphos for chickpea food seed protection up to150 days of storage.

\section{Materials And Methods}

\section{Collection of chickpea food seed samples and Mycological analysis}

Samples of chickpea food seed kept in storage ( 6 to 8 months) of were collected from 25 sites( 10 grocery stores +15 farmer's stores) of Gorakhpur(UP) and Gurgaon (Haryana) in presterilized polyethylene bags of one litre. The mycological flora identification analyses of chickpea food seeds were conducted both through agar plate ${ }^{9}$ using Czapek dox agar medium(each containing $15 \mathrm{ml}$ medium) and standard blotter ${ }^{10}$ techniques.About 100 seeds were equidistantly placed on Czapeks dox agar medium in separate Petri plates in agar plate technique.Each contained 5 seeds.In blotter test, seeds were similarly plated on three layered moistened blotter pads in sterilized Petriplates. These assay plates were then incubated at $25 \pm 2{ }^{\circ} \mathrm{C}$ and observed daily from 7-to-15 days for observing growth of fungal colonies.Fungal colonies on the seeds were isolated and subcultured.The microscopic and macroscopic observations were taken and identified with the help of available literature $11,12,13,14$ as well as by comparing their morphological and cultural characteristics with authentic cultures maintained in Mycology Lab,Dept of Botany,University of Gorakhpur and AIB,Amity University Haryana.For detecting the internal seed borne pathogens,chickpeaseeds were first surface sterilized with aqueous $0.1 \%$ mercuric chloride for two minutes. They were then washed with double distilled water and then subjected to agar plate and standard blotter techniques for isolation of the fungi. Each fungal species (\%) associated with seeds samples of chickpea was estimated.

\section{Culturing Insect- Callosobruchus chinensis (L.)}

This was done from infested stored chickpea seeds collected from twenty five places of Uttar Pradesh, India and identified ${ }^{15,16}$. This was maintained in newly harvested chickpea seeds incubated at laboratory $\left(28 \pm 2^{\circ} \mathrm{C}\right.$ temperature) in darkness to obtained same aged insects. No insecticide treatment was given.

\section{Evaluation of deterioration caused by dominant fungi and insect}

For studying effect of dominant fungal species viz., Aspergillus flavus, A. niger, Fusarium oxysporum causing deterioration parameters viz.,respect to weight loss,seedgermination,carbohydrate and protein content was evaluated. This was conducted by taking local variety of freshly harvested sterilized chickpea seeds in containers of presterilized polyetylene bags that was having of ( $250 \mathrm{~g} \mathrm{seeds/bag).This} \mathrm{was}$ inoculated by two discs ( $7 \mathrm{~mm}$ diam) of these dominant different fungal species separately. Similarily 6 insect - Callosobruchus chinensis were taken and inoculated in presterilized polyetylene bags separately. The insect inoculated chickpea seed samples were incubated for storage up to 21 days in laboratory conditions at room temperature. The Experiments were conducted twice and each trial was having five replicates.

The deterioration caused by fungi/insect in terms of carbohydrate content in chickpea seed were studied following Anthrone method ${ }^{17}$. The Carbohydrates were dehydrated through Conc. $\mathrm{H} 2 \mathrm{SO} 4$ for forming furfural. Furfural then condenses with anthrone (10-Keto-9, 10 dihydro anthracene) to form a blue-green coloured complex.This was measured through calorimeter at $630 \mathrm{~nm}$. The protein content estimation was done following Lowry et al. ${ }^{18}$ by taking bovine serum albumin as standard. The optical density of each chickpea seed sample was taken at $650 \mathrm{~nm}$.

\section{Extraction of essential oil from Lavang-Syzygiumaromaticum(Myrtaceae) and leaves of sowa(Anethum graveolens L. (dill) and Fumigant fungitoxicity testing against fungi}

The essential oil was extracted from $200 \mathrm{~g}$ dried and ground Lavang, and $1000 \mathrm{~g}$ chopped leaves of sowa(Anethum gravelens) through hydrodistillation in 2 litre water in Clevenger's apparatus at $90 \pm 2{ }^{\circ} \mathrm{C}$ up to $5-9$ hours separately. The isolated essential oils were dried over anhydrous sodium sulphate separately. This was stored at $4^{\circ} \mathrm{C}$ under sterile condition for further use. For developing fungitoxic fumigant activity of clove buds-S.aromaticum(Myrtaceae) and leaves of sowa(Anethum graveolens $L$. (dill) Apiaceae against fungal species were evaluated separately through Inverted petri plate technique ${ }^{19}$ at $500 \mathrm{ppm}(0.025 \mathrm{ml})$.

\section{Physiochemical properties of Lavang and sowa oil}

The oil was characterized by determination of Specific gravity,Refractive index ,Optical rotation ,Acid value,Ester value, Saponification value and Solubility characteristic following the methods of Langenau 20.

\section{GC-MS Investigations}


Here required amount $(0.1 \mu \mathrm{l})$ of essential oil of Lavang and dill leaf were taken for analysis of GC and GC-MS analysis separately. The GC was framed of an Agilent Technology $6890 \mathrm{~N}$ gas chromatograph data handling system. This having equipped by a split-splitless injector.The split ratio taken was 50 : 1.This fitted with a FID(flame ionization detector) by using $\mathrm{N} 2$ being a carrier gas that was in a flow rate $1 \mathrm{ml} \cdot \mathrm{min}^{-1}$. The column taken was ( $30 \mathrm{~m} \times 0.32 \mathrm{~mm}, 0.25 \mu \mathrm{m}$ film thickness) HP-5 capillary column. The temperature taken for the study was: starting temperature of $60^{\circ} \mathrm{C}$ (hold $-2 \mathrm{~min}$ ) programmed at a rate of $3^{\circ} \mathrm{C} \cdot \mathrm{min}^{-1}$ to a final temperature of $220^{\circ} \mathrm{C}$ (hold $-5 \mathrm{~min}$ ). Temperatures of the injector and flame ionization detector (FID) were kept at $210^{\circ} \mathrm{C}$ and $250^{\circ} \mathrm{C}$ respectively. The identification of Compound was carried out by calculating their Kovats indices ${ }^{21}$ and by doing comparison of mass spectra which is reported in the literature ${ }^{22}$ and that is present in database of GC-MS computer (NIST 98 and Wiley-5).

\section{Fungitoxic and insect repellent investigations of essential oil of Lavang and sowa leaf}

The minimum inhibitory concentration(MIC) of Lavang and sowa leaf essential oil was investigated following poisoned food technique ${ }^{23}$. Here various concentration of the Lavang and sowa leaf essential oil which covered from 200 to 800 ppm were prepared.This was done through dissolving requisite amount of oil in $0.5 \mathrm{ml}$ acetone and then mixing with $9.5 \mathrm{mlCzapeks-dox}$ agar medium separately.For control sets Petridishes with acetone and medium not having of Lavang and sowa leaf essential oil were taken. The Fungal discs of dominant fungal species (5mm diam) which was taken from seven days old culture(periphery region) of each of test fungi viz.,Aspergillus flavus, A. niger, Fusarium oxysporum were inoculated aseptically at treatment and control sets each separately.All the sets were kept for 6 days at $28 \pm 2{ }^{0} \mathrm{C}$.The Diameters of fungal colony of control and treatment sets of Aspergillus flavus, A. niger, Fusarium oxysporum were taken separately in mutually perpendicular directions on the $7^{\text {th }}$ day. The Experiments were done twice.This was having of 3 replicates. The repellent activity of the essential oil of Lavang and sowa leaf against insect-Callosobruchus chinensis was done following the method of Tripathi and Kumar ${ }^{24}$ with slight modification.

To find out nature of antifungal properties of the Lavang and sowa leaf oil treated fungal disc of Aspergillus flavus, A. niger, Fusarium oxysporum that was showing complete inhibition of mycelial growth upto $7^{\text {th }}$ day were taken. This were washed with sterile water.This was placed again on fresh solidified medium for taking an observation of revival of mycelial growth.The fungitoxic spectrum of essential oil of Lavang, sowa leaf and mixture oil(1:1 ratio) were investigated on various fungi isolated from seeds samples of chickpea.The effect of autoclaving and storage on the fungitoxicity of Lavang and sowa leaf oil and mixture oil was determined ${ }^{25}$.Each experiment was repeated twice and had 3 replicates.

\section{Formulation of mixture oil (Syzygium aromaticum(Myrtaceae) and leaves of sowa(Anethum graveolens L.) and Comparison of efficacy with synthetic fumigant-Salphos}

As the cost of $100 \mathrm{~g}$ Lavang is Rs299 which is high for farmers and cost of sowa leaf is Rs.10-15/kg(even free in our farmers field), so for developing low cost formulation mixture of Lavang and sowa leaf oil in 1:5 ratio was prepared.For this $1 \mathrm{ml}$ of Lavang oil was taken in clean(ed) sterilized test tubes and added $5 \mathrm{ml}$ of sowa leaf essential oil.

The chickpea fresh seeds locally available were collected. The seeds were sun dried for keeping in presterilized airtight tin containers. For testing in vivo preservative potential method of Kumar ${ }^{25}$ were followed with slight modification.For this mixture oil, salphos(Fig 3) (Aluminium phosphide) tin containers and polyethylene bags were taken. Tin containers and polyethylene bags farmers are using in this area for chickpea storage. Since mixture oil are in liquid form $200 \mathrm{~g}$ of chick pea seeds were taken in $250 \mathrm{ml}$ size tin containers and polyethylene bags. For chickpea seeds treating did preparation of two doses of oil mixture firstly by taking $1000 \mathrm{ppm}(0.50 \mathrm{ml})$ and another $1500 \mathrm{ppm}(0.76 \mathrm{ml})$ in tin containers and polyethylene bags of $250 \mathrm{ml}$ capacity having of $200 \mathrm{~g}$ seeds separately. The sterile cotton swabs weighing $0.50 \mathrm{~g}$ by soaking of oil doses were wrapped in sterilized muslin cloth weighing of $0.75 \mathrm{~g}$ were placed at mid point of each container of chickpea seeds. Similarily, $200 \mathrm{~g}$ samples of chickpea seeds were treated with salphos from $1000 \mathrm{ppm}(0.50 \mathrm{~g})$ or $1500 \mathrm{ppm}(0.76 \mathrm{~g})$ of tablet in $250 \mathrm{ml}$ containers. These were stored in a cabinet for 150 days in the laboratory at room temperature. Each set was having of five replicates. Fungal investigations on seeds were carried out by agar plate technique of Muskett ${ }^{9}$ (1948) and the standard blotter technique ${ }^{10}$ of De Tempe (1953). The insects were examined by hand lens.

In negative control sets, the seeds were dressed with requisite amount of acetone in place of the mixture oil(Lavang and sowa leaf oil) and salphos. The tin and polyethylene containers were sealed airtight. These were incubated at room temperature at $75 \pm 5 \%$ humidity. Observations for presence/absence of mycoflora were made after 25 days observed upto 150 days separately.After 150 days of storage,germination tests were done by taking 100 seeds randomly from each test lot.This then was aseptically placed in presterilized petridishes containing three layers of moistened blotting paper.These were moistened with sterile water at 3 day intervals.All sets were incubated at $28 \pm 2{ }^{\circ} \mathrm{C}$ in a dark chamber and germination was assessed from the 2 nd to 10 th day.

\section{Results And Discussion}


To examine the storage losses, 25 samples of chick pea seeds were collected from grocery stores of Gurgaon and Gorakhpur for examination of associated fungi(Fig.1) and insects. Seventeen fungal species viz., Alternaria alternata, Aspergillus flavus, A. niger, A. ochraceous,A.oryzae, A. terreus, A. sydowi, Chaetomium globosum, Colletotrichum dematium, Curvularialunata, Fusarium moniliforme, F. oxysporum, F. solani, Penicillium italicum, Rhizopus stolonifer, Rhizoctonia solani, Sclerotium rolfsii were found to be associated in stored chick pea (Cicer arietinum L.) seeds on the basis of microscopic and macroscopic observations. The agar plate method of study revealed presence of 17 fungi while blotter had 13 fungal species. In these Aspergillus flavus, A. niger, Fusarium oxysporum had dominance in terms of per cent occurrence showing $55.3,50.4,40.1 .0 \%$ on blotter and $51.0,52.0,50.0 \%$ in agar plates, respectively(Table 1 ).

The insect analysis revealed presence of only one species of Bruchid (Callosobruchus chinensis L) in all the 25 samples(Fig.2).The adult beetle is chockalate coloured ,oval shaped,3 - 4 mm long.The body is pointed towards front.More attacks were observed during July-August in the stores. This showed feeding by making a small hole.There was presence of white eggs in Infested seeds on the surface and round exit holes with the 'flap' of seed coat.

Time to time fungal species were observed by various workers viz.,Nine fungal species -Alternaria alternata, Aspergillus flavus, Aspergillus niger, Curvularialunata [Cochliobolus lunatus], Fusarium moniliforme [Gibberella moniliformis], Helminthosporium sativum [Cochliobolus sativum], Mucorsp., Penicillium notatum and Rhizopus nigricans [R. stolonifer] fromKumarganj, Faizabad India ${ }^{26}$ (Singh et al.,2005); thirty fungal species were isolated from these seeds and most abundant-among these, were Alternaria alternata, Chaetomium spp., Penicillium citrinum, Aspergillus niger, A. flavus, Rhizopus nigricans, Fusarium oxysporum ${ }^{27}$ (Zaidi and Pathak,2013); many fungal species viz. Alternaria alternata, Aspergillus terrus, A. flavus, A. fumigatus, A. niger, Botrytis sp., Cladosporium, Curvularialunata, Fusarium solani, F. moniliforme, F. oxysporum, Macrophominaphaseolina, Penicillium notatum, Rhizoctonia sp. and Rhizopus nigricans ${ }^{28}$ (Ghangoaker and Kshirsagar ,2013);seven fungal species such as Alternaria alternata, Aspergillus flavus , A. niger, A. fumigatus, Curvularialunata, Fusarium monoliforme and Rhizoctonia solani $^{29}$ (Singh, 2014); Thirteen different fungi like Actinomucor repens, Alternaria alternata, Aspergillus flavus, A. fumigatus, A. niger, A. ochraceus, Cladosporium sp., Fusarium oxysporum, Fusarium sp., Mucor varians, Penicillium notatum, Phomaherbarum, Rhizopus stolonifer ${ }^{30}$ ( Sontakke and Hedawoo ,2014); Aspergillus niger (83\%), Fusarium solani (79\%), Aspergillus flavus (75\%), Alternaria alternata (60\%) and Aspergillus nidulans (57\%). Minimum seed borne fungi were reported to beRhizopus stolonifer, and Fusarium oxysporum ${ }^{31}$ (Padmaja et al.,2015); 14 fungi comprising 12 genera namely Aspergillus flavus, Aspergillus niger, Aspergillus sp, Botryodiplodiatheobromae, Botryti cinerea, Curvularialunata, Chaetomium globosum, Cladosporium sp., Colletotrichum dematium, Fusarium oxysporum, Macrophominaphasaelina, Rhizoctonia solani, Rhizopus stolonifer and Stemphylium sarciniforme ${ }^{32}$ (Hossain et al.,2018); Nine fungal species namely Alternaria alternata (Fr.) Keissl., Aspergillus flavus Link, Aspergillus nigervan Tieghem, Aspergillus oryzae (Ahlburg) E. Cohn, Fusarium oxysporumSchlecht. Emend. Snyder \& Hansen, Macrophominaphaseolina (Tassi) Goid., Mucor sp., Penicillium italicumWehmer and Sclerotium rolfsii Sacc ${ }^{33}$ (Javid et al.,2019),A. flavus, A.fumigatus and A.niger, Drechslera tetramera, Fusarium moniliforme, Rhizopus stolonifer ${ }^{34}$. The fungal species viz.,Chaetomium globosum, Colletotrichum dematium,Penicilliumitalicum, Sclerotium rolfsii(could)did not grow on blotters.A study ${ }^{26}$ (Singh et al.,2005) revealed that $P$. notatum developed on agar plate only ${ }^{26}$ (Singh et al.,2005).This may be because of fungal nutritional requirements. The no of fungal species were reduced in surface sterilized seeds which indicates that many of the fungi were located on seed coat.The sterile chick pea seeds with $0.1 \%$ Mercuric chloride projected less per cent occurrence of fungal colonies(Table 1 ).

The seed mycoflora devalue the seed quality, reduce its nutritional value and cause a germination failure of the seedlings and of the crop raised from such infected seeds ${ }^{27}$ ( Zaidi and Pathak,2013). Based on the data in the Table 2,A. flavus, A. niger,F.oxysporum and the insect species - $C$. chinensis played an important role in weight loss,seed germination,carbohydrate and protein content. A.flavus inoculated seeds showed $50 \%$, $A$. niger 53\%,F.oxysporum 40\% while insect inoculated 39\% while control set without fungus or insect inoculation showed $90-98 \%$ seed germination. The seeds inoculated with fungi/insects showed 30.1,29.4,28.7,27.4\% carbohydrate content while control set showed $61 \%$.It is evident from Table 2that fungal/insect inoculated chickpea seeds after 21 days of storage had 10.3,9.3.10.4,8.5\%protein content while control seeds were having $20 \%$ protein content. On account of wide occurrence and their pathogenicity these were selected as test organisms.

Storage conditions and containers are significant in preservation and maintenance of healthy seed during post harvest period ${ }^{35}$ (Kandhare,2018). The variation in fungal species may be due to different isolation periods and different storage containers. The isolated species in present investigation are different may be due to different climatic conditions.

The yield of essential oil by hydrodistillation of Lavang(clove bud) was $13.57 \%$ while the leaves of $A$.graveolens $L$. was $1.05 \%$ respectively. Fumigant fungitoxic action study of Both oils at 500 ppm $(0.025 \mathrm{ml})$ concentration showed 100\%inhibition against Aspergillus flavus, A. niger, Fusarium oxysporum separately.

It has been extensively reported that plant based essential oils are alternative to synthetic pesticides since they are known to have minimal environmental impact and danger to consumers ${ }^{36-38}$ (Alpaet al., 2010; Katochet al.,2012, Sharma et al.,2016). 
For prescription an appropriate dose for the determination of $\mathrm{MIC}$ (minimum inhibitory concentration)is necessary. In the study, Lavang oil displayed highest antifungal activity against Aspergillus flavus, A. niger, Fusarium oxysporum and completetely inhibited mycelial growth(100\%)of fungal speciesat 300ppm and found fungicidal at 400ppm.Sowa oil showed complete inhibition at 400ppm and found fungicidal at 500ppm. While mixture oil showed complete inhibition (100\%) and fungicidal action at 400ppm against domiant fungi- Aspergillus flavus, A. niger, Fusarium oxysporum(Table 3). Both Lavang and sowa oil showed 100 per cent repellent activity at $0.01 \mathrm{ml}$ dose.This was also cidal at $0.02 \mathrm{ml}$ dose against test insect-Callosobruchus chinensis.Mixture of both oils was cidal at $0.02 \mathrm{ml}$ dose.

The study on mixture of oils for antifungal spectrum revealed it knocked all seventeen fungi( $A$. alternata, Aspergillus flavus, $A$. niger, $A$. ochraceous, A. oryzae, A. terreus, A. sydowi, Chaetomium globosum, Colletotrichum dematium, Curvularia lunata, Fusarium moniliforme, $F$. oxysporum, F. solani, Penicillium italicum, Rhizopus stolonifer, Rhizoctonia solani, Sclerotium rolfsii)at 500ppm concentration.It showed 70-93\% inhibitory activity against all 17 fungi at 300ppm isolated from chickpea seeds(Table 4).The oil mixture's activity was not affected by autoclaving at $15 \mathrm{lb} / \mathrm{psi}$ at $120^{\circ} \mathrm{C}$.lt (safely) inhibited fungal growth even after storage of oil upto150 days(Table 5).

In this study,Lavang oil showed MIC 300ppm,Sowa oil 400ppm while the mixture had 400ppm against Aspergillus flavus, A. niger, Fusarium oxysporum.Previous studies depicted that there is a marked variation in the MIC of different plant oils at different concentrations against $A$.niger viz.,Ocimumadscendensat 200ppm ${ }^{39}$ (Asthana and Singh,1981); Syzygiumaromaticum(L.)Merrilland Perry 200ppm ${ }^{40}$ (Khan,1993); Cedrus deodara at 1000ppm and Trachyspermum ammi at 500ppm ${ }^{41}$ (Singh and Tripathi,1999);Adhatoda vasicaat 500ppm ${ }^{42}$ (Kumar,2014). Cuminumcyminumat 400ppm ${ }^{25}$ (Kumar,2016); Tinospora cordifolia at 400ppm ${ }^{43}$ (Kumar et al.,2020).The differences in the MIC of various plant oils may be due totheir being different in chemical constituents or other chemical or physical parameters.

A fungicide must retain its fungitoxicity even after autoclaving ${ }^{44}$ (Wellman,1967). The fungitoxicity of oil mixture (Lavang and sowa leaf oil )retained the fungitoxicity(Table 4) even after autoclaving(15lbs/psi)like that of Ageratum conyzoides ${ }^{45}$ (Dixit et al.,1995); Nardostachysjatamansi ${ }^{46}$ (Mishra et al.,1995);Adhatodavasica oil ${ }^{42}$ (Kumar,2014); Cuminum cyminum ${ }^{25}$ (Kumar,2016)and Tinospora cordifolia ${ }^{47}$ (Kumar et al.,2020). This quality of oil will facilitate the isolation of their constituents in active state.It is also evident that a fungicide must be able to retain its activity for a long storage period.The fungitoxic factor in the oil of Adenocalyma allicea was lost within 21 day of storage ${ }^{48}$ (Chaturvedi,1979) while retained for longer periods in the oils of Ageratum conyzoides ${ }^{45}$ (Dixit et al.,1995); Trachyspermum ammi ${ }^{41}$ (Singh and Tripathi,1999);Adhatoda vasica ${ }^{42}$ (Kumar,2014);Cuminum cyminum ${ }^{25}$ (Kumar,2016)and Tinospora cordifolia ${ }^{47}$ (Kumar,2017;). The antifungal Toxicity of mixture oil (Lavang and sowa leaf oil )was not affected by storage upto 150days.It may be suggested that the oil mixture (Lavang and sowa leaf oil )can be safely stored for long periods(150 days) without having any adverse effecton toxicity.

The physiochemical properties of the Lavang and sowa leaf oil are recorded in Table6. GC-MS analysis of Lavang oil revealed major components viz., $75.63 \%$ eugenol, $12.67 \%$ caryophyllene, $8.34 \%$ eugenyl acetate and $1.63 \%$ a-humulene while the minor components were $0.03 \%$ elemene, $0.06 \%$ a-cadinene and $0.07 \%$ ledol. The GC-MS analysis of sowa leaf oil showed presence of major constituents viz.,25.14\% apiole ,12.79\% o-cymene ,15.67\% a-thujene, $7.13 \%$-phellandrene while minor components viz., 4.87\% exo-2-hydroxycineol ,4.13\% limonene ,2.83\% 3isoproyl-4-methyl-1-pentyn-3-ol ,2.14\% myristicine (2.16\%) and $2.13 \%$ dithydroumbell the oil ulone .

The study also showed that mixture oil (Lavang and sowa leaf oil )was more effective than salphos. It is evident from Table 7,that salphos controlled a maximum of 3 fungi while the oil mixture showed complete seed protection showing growth of no fungi and insect-Callosobruchus chinensis even after 150 days of storage.It shows its potential efficacy as the Seed Protectant as it is able to protect all 17 fungi.(Table 7). Hence it appears that mixture oil (Lavang and sowa leaf oil )increases the chickpea seeds shelf life. The seeds which served as control, showed proliferation of all 17 fungal species after 150 days of storage.Our study revealed that mixture oil (Lavang and sowa leaf oil)was more fungitoxic than salphos used in our experiments. No insect species was observed in the oil mixture treated seeds in both containers while it was present in the sulphos treated and control sets. The antifungal and insect repellent propertyof this mixture oil (Lavang and sowa leaf oil )suggests to exploit it as an ideal protectant of chickpea seeds during storage.

After 150 days of storage,germination tests revealed $90-95 \%$ seed germination in oils mixture's treated sets,salphos treated sets revealed $60-65 \%$ while control set revealed $50-55 \%$ seed germination from seeds of both containers. The mixture oil showed no adverse effect on seedling growth and general health and morphology of plants. Thus,themixture oil (Lavang and sowa leaf oil )showed great potential as protective agent for chickpea seeds against spoilage by fungi and insects during storage.

\section{Conclusion}

Our study revealed that oilmixture (Lavang and sowa leaf oil )was more fungitoxic than tested synthetic pesticides-Salphos.It completely protected from Bruchid (Callosobruchus chinensis). Thisindicates its possibility of its exploitation in the form of seed protectant of chickpea food seedsfor storage. Lavang and sowa is an indigenous plant.It grows luxuriantly.Essential oil can be easily made available upon extraction and formulations can be prepared. It will be a renewable source of fungitoxicantand bruchid repellent which will be keeping chickpea food seeds without damage.There will be protection of edible food by edible oils without any toxic effect on human and environment will remain safe.

Page 6/13 


\section{Declarations}

\section{Conflict of interest statement}

We declare that there is no conflict of interest.

\section{Acknowledgment}

Authors are thankful to the Amity University Haryana authorities and Head, Dept of Botany DDU Gorakhpur University,Gorakhpur for the facilities and constant encouragement.

\section{References}

1. Cram,M and Fraedrich S.Seed diseases and seedborne pathogens of North America. Tree Planters' Notes 53 (2): $35-44(2010)$.

2. Singh YP. and Sumbali G. Efficacy of leaf extracts and essential oil of some plant species against Penicillium expansumrot of apples. Ann. Pl. Protec. Sci., 15: 135-139 (2007)

3. Sahani, R.K. and Saxena A.R.Fungitoxic properties of medicinal and aromatic plants against Fusarium oxysporumfsppisi.Ann. Pl. Protec. Sci.,17: 146-148(2009).

4. Hyldgaard M, MygindT.,Meyer RL .Essential oils in food preservation: mode of action, synergies, and interactions with food matrix components. Front. Microbio. 3:12(2012

5. Amelia B, Saepudin, E.,Cahyana, AH.,Rahayu, DU.,SulistyoningrumAS and Haib,J.GC-MS analysis of clove (Syzygium aromaticum) bud essential oil from Java and Manado. AIP Conference Proceedings,1862: 030082(2017).

6. Baslas BK and Baslas, RK.Chemical Studies into the Essential Oils from the Plants of Anethum graveolens\&Anethamsowa (Dill Oils). Indian Perfumer, 15: 27- 29(1971).

7. Woolf,A.Essential Oil Poisoning. J. Clinical Toxicol., 37: 721-727 (1999).

8. Vats N and Pandey R.Analysis of oil extracted from Anethum sowa .Int. J. Chem. Sci.: 10(4): 2010-2014 (2012).

9. Muskett,A,E.Technique for the examination of seed for the presence of seed borne fungi. Trans.Br.Mycol.Soc.,30;74-83(1948).

10. De Tempe,J.The blotter method of seed health testing.Proc,Int.Seed test Assocn.,28;133-151(1953).

11. Raper, KB. and Thom, C.A Manual of the Penicillia. The Williams \& Wilkins Company, Baltimore(1949).

12. Raper, KB. and Fennell, DI.The Genus Aspergillus. Williams and Wilkins, Philadelphia, 686 p. (1965).

13. Ellis, MB. Dematiaceous Hyphomycetes. Commonwealth Mycological Institute, Kew, Surrey, England, 608p. (1971).

14. Ellis MB. More Dematiaceous Hyphomycetes. CAB International Mycological Institute, Kew, UK. 507 p. (1976).

15. Kingsolver JM.Handbook of the Bruchidae of the United States and Canada USDA, Technical Bulletin 1912 (2 vols.) (2004).

16. Bousquet Y., Bouchard P., Davies AE., Sikes DS.Checklist of beetles (Coleoptera) of Canada and Alaska. Second edition. ZooKeys, 360: 1402(2013).

17. Hedge, JE and Hofreiter, BT. In: Carbohydrate Chemistry 17(Eds Whistler R L and Be Miller, J N) Academic Press New York (1962).

18. Lowry OH., Rozenbrough NJ., Farr AL., Randall RJ. Protein measurement with the folin phenol reagent. The Journal of Biological Chemistry 93: 265(1951).

19. Bocher, O.E. Antibiotics. In modern method of plant analysis Vol. III (Peach K and Tracey M.V. eds.) Springer Verlag Berlin p.651(1938).

20. Langenau,EE.The examination and analysis of essential oils;synthetics and isolates.In:Guenther,E.(Ed.),The Essential Oils,vol.1.Kriger Publishing Co.,Huntington,New York,pp.227-348(1948).

21. Davies NW. Gas chromatographic retention indices of monoterpenes and sesquiterpenes on methyl silicone an Carbowax $20 \mathrm{M}$ phases. Journal of Chromatography 503: 1-24(1990).

22. Adams RP.Identification of Essential Oil Components by Gas Chromatography/Mass Spectroscopy. Allured Publishing Inc., Carol Stream, IL, USA, $469 \mathrm{pp}(1995)$.

23. Grover, RK., Moore, JD . Toximetric studies of fungicides against brown rot organism Sclerotiniafructicola and S. laxa. Phytopathology, 52: 876-880(1962).

24. Tripathi NN and Kumar N.Putranjiva oil - Promising herbal preservative for peanut during storage". Journal of stored Products Research, 43 : 435-442(2007).

25. Kumar N.Fumigant efficacy of Cumin essential oil on fungi and insect infesting Pisum sativum L. during storage. Annals of Plant Protection Sciences, 24(1): 196-201(2016). 
26. Singh K.,Singh, AK..,Singh, RP.Detection of seed mycoflora of chick pea (Cicer arietinumL.). Annals of Plant Protection Sciences,13:167171(2005).

27. Zaidi, RK.and Pathak,N.Evaluation of seed infection of fungi in Chickpea. e-Journal of Science \& Technology, 8 (2): 27-36(2013).

28. Ghangaokar NM, Kshirsagar AD.Study of seed borne fungi of different legumes. Trends in Life Sciences, 2(1): 32-35(2013).

29. Singh VK.Detection of mycoflora associated with Cicer arietinum seeds by agar plate method with PDA. Weekly Science Research Journal, 1(30): 1-4(2014).

30. Sontakke NR and Hedawoo GB. Mycoflora associated with seeds of chickpea. Int. J. of Life Sciences, Special Issue A2: 27-30(2014).

31. Padmaja MC, Andoji YS , Kambl SS.Detection of seed borne mycoflora from different categories of chickpea (Cicer arietinum) L.RJLBPCS 1(4):203-205(2015).

32. Hossain, M., Imran, M., Bhuiyan, K., Habib, M., \&lkrum, M.Prevalence of Seed Borne Fungi Associated with Chickpea Seeds and Biological and Chemical Control of Fusarium oxysporum Causing Wilt Disease. Journal of Environmental Science and Natural Resources, 10(2): 4554(2018).

33. Javaid, Arshad, Khan, Iqra . Mycoflora associated with seeds of different varieties of chickpea and its effect on germination and radicle growth. International Journal of Biology and Biotechnology. 16: 175-179(2019).

34. Kandhare AS . The Common Mycoflora in Four Legumes Seeds and their Effects on Seedling Vigor index Kandhare Ashok Sadhu. Middle East Journal of Agriculture Research;:215-219(2020).

35. Kandhare AS.Post harvest preservation in different containers, pathogenesis and management of chickpea (Cicer arietinum L.) seed health. Biodiversity Int J. 2(6):562-565(2018).

36. Nabil E. El-Wakeil.Botanical Pesticides and Their Mode of Action . Gesunde Pflanzen 65:125-149(2013).

37. Katoch, R., Thakur, M. and Paul, Y.S .Antifungal activity of the essential oils of Chromolaenaadenophorum, Ageratum conyzoidesandLantana camara. Indian Phytopath. 65(4): 409-411(2012).

38. Sharma M,Sharma PC ,Kaundal K and Sharma H.Antifungal activity assessment of essential oil of bitter apricot (Prunus armeniaca) kernels. IndianPhytopath69 (3) : 290-293(2016).

39. Asthana,A and Singh,A.K.Fungitoxic properties of essential oil of Ocimumadscendens. Journal of Indian Botanical Society Supplement, 60;13(1981).

40. Khan,S.A.Control of fungal and insect deterioration of blackgram during storage by some higher plants. PhD thesis GorakhpurUniversity,Gorakhpur,India(1993).

41. Singh,J and Tripathi,NN.Inhibition of storage fungi of black gram(Vigna mungo L) by some essential oils. Flavour Fragrance J. 14;1-4(1999).

42. Kumar N . Adhatoda vasica leaf oil-a potential fumigant preservative for groundnut during storage. Indo American Journal of Pharmaceutical Sciences ,1(6): 392-401(2014).

43. Kumar,N.,Khurana SM Paul and Pandey VN.Antifungal activity of essential oil of Tinosporacordifolia against storage fungi of wheat .Journal Medicinal Plants 12:150-157(2020).

44. Wellman,R.H.Commercial development of fungicides.In;Plant pathology Problem and Progress Eds Holtan et al.,1908-1958.Indian University Press,Allahabad, India(1967).

45. Dixit, SN, Chandra,H, Tiwari,R and Dixit,V.Development of botanical fungicide against blue mould of mandarins.J.Stored Prod.Res.,31(2);165172(1995).

46. Mishra D., Chaturvedi,R.V and Tripathi, S.C.The fungitoxic effect of the essential oil of the herb Nardostachysjatamansi D.C. Tropical Agri,72(1);48-52(1995).

47. Kumar N. In vivo preservative potential of neem Giloy-Tinospora cordifolia (willd.) Miers ex hook. F. and thoms leaf essential oil for groundnut (Arachis hypogaea) seeds. Int J Pharm Sci Res .,8(10): 4291-97(1997).

48. Chaturvedi,R.Evaluation of higher plants for their fungitoxicity against Helminthosporiumoryzae.Ph.D Thesis Gorakhpur University,Gorakhpur,India(1979).

\section{Tables}

Table 1. Mycological analysis of stored food seeds of chickpea 


\begin{tabular}{|c|c|c|c|c|}
\hline \multirow[t]{2}{*}{ Fungi recorded } & \multicolumn{2}{|c|}{ Blotter method } & \multicolumn{2}{|c|}{ Agar plate method } \\
\hline & US & SS & US & SS \\
\hline Alternaria alternata(Fr.) Keissler & $4.1 \pm 0.05$ & $2.0 \pm 0.03$ & $4.1 \pm 0.03$ & - \\
\hline Aspergillus flavus Link & $55.3 \pm 0.08$ & $20.1 \pm 0.09$ & $51.0 \pm 0.16$ & $24.9 \pm 0.06$ \\
\hline A. nigervan Tieghem & $50.4 \pm 0.27$ & $23.7 \pm 0.08$ & $52.0 \pm 0.26$ & $27.7 \pm 0.03$ \\
\hline A. ochraceous Wilhelm & $13.0 \pm 0.17$ & $4.5 \pm 0.03$ & $12.0 \pm 0.25$ & $6.7 \pm 0.13$ \\
\hline A.oryzae (Ahlburg) E. Cohn & $3.0 \pm 0.06$ & - & $3.1 \pm 0.05$ & - \\
\hline A. terreusThom & $11.0 \pm 0.17$ & $3.5 \pm 0.17$ & $20.6 \pm 0.27$ & $5.7 \pm 0.17$ \\
\hline A. sydowi(Bainier and Sartory) & $4.3 \pm 0.07$ & $2.1 \pm 0.06$ & $6.0 \pm 0.05$ & $1.0 \pm 0.04$ \\
\hline \multicolumn{5}{|l|}{ Thom and Church } \\
\hline Chaetomium globosumKunze & - & - & $16.0 \pm 0.05$ & $1.0 \pm 0.04$ \\
\hline Colletotrichum dematium (Pers.) Grove & - & - & $6.0 \pm 0.04$ & $1.0 \pm 0.03$ \\
\hline Curvularialunata (Wakker) Boedijn & $4.1 \pm 0.05$ & $2.1 \pm 0.04$ & $6.0 \pm 0.03$ & $1.0 \pm 0.04$ \\
\hline Fusarium moniliformeSheldon & $3.2 \pm 0.01$ & $3.0 \pm 0.02$ & $4.1 \pm 0.09$ & - \\
\hline F. oxysporumvon Schlechtendal & $40.1 \pm 0.31$ & $17.6 \pm 0.26$ & $50.0 \pm 0.31$ & $27.7 \pm 0.25$ \\
\hline F. solani(Mart.) Sacc. & $2.1 \pm 0.04$ & $2.3 \pm 0.06$ & $3.1 \pm 0.05$ & $1.3 \pm 0.05$ \\
\hline Penicillium italicumWehmer & - & - & $2.2 \pm 0.04$ & - \\
\hline Rhizopus stoloniferVuillemin & $3.3 \pm 0.03$ & - & $0.2 \pm 0.01$ & - \\
\hline Rhizoctonia solani J.G. Kühn & $4.2 \pm 0.07$ & $2.1 \pm 0.06$ & $6.0 \pm 0.05$ & $1.0 \pm 0.04$ \\
\hline Sclerotium rolfsiiSacc. & - & - & $6.2 \pm 0.03$ & $2.0 \pm 0.03$ \\
\hline
\end{tabular}

-:Absence of fungal species;US:Unsterilized seeds; SS:Sterilized seeds

*Values given are mean of three replicates;SD=Standard Deviation

Table 2. Evaluation of effect of Fungal/insect species on chickpea seeds after 21 days storage

\begin{tabular}{|lllllllll|}
\hline Fungus/Insect species & \multicolumn{2}{l}{ Weight loss(g) } & \multicolumn{2}{l}{ Germination(\%) } & \multicolumn{2}{l|}{ Carbohydrate(\%)? } & \multicolumn{2}{l|}{ Protein (\%) } \\
\cline { 2 - 9 } & C & T & C & T & C & T & C & T \\
\hline Aspergillus flavus & - & 0.189 & 95 & 50 & 61 & 30.1 & 20 & 10.3 \\
\hline A. niger & - & 0.183 & 98 & 53 & 61 & 29.4 & 20 & 9.3 \\
\hline F.oxysporum & - & 0.181 & 90 & 40 & 61 & 28.7 & 20 & 10.4 \\
\hline Callosobruchus chinensis & - & 0.185 & 96 & 39 & 61 & 27.4 & 20 & 8.5 \\
\hline
\end{tabular}

C:Control;T:Treatment; - Nil

Table 3. Minimum Inhibition Concentration (MIC) of Lavang, sowaleafoil and mixture oil 


\begin{tabular}{|c|c|c|c|c|c|c|c|c|c|}
\hline \multirow{4}{*}{$\begin{array}{l}\text { Oil } \\
\text { concentration } \\
\text { (ppm) }\end{array}$} & \multicolumn{9}{|c|}{ Percent inhibition of fungal species by oil/mixture oil } \\
\hline & \multicolumn{3}{|l|}{ Lavang oil } & \multicolumn{3}{|l|}{ Sowa oil } & \multicolumn{3}{|c|}{ Mixed Lavang and sowaoils } \\
\hline & A. flavus & A. & $F$ & A. & A. & $F$ & A. & A. & $F$ \\
\hline & & niger & oxysporum & flavus & niger & oxysporum & Flavus & niger & oxysporum \\
\hline 100 & $60 \pm 0.11$ & $62 \pm 0.10$ & $65 \pm 0.10$ & $30 \pm 0.10$ & $31 \pm 0.11$ & $32 \pm 0.12$ & $60 \pm 0.10$ & $62 \pm 0.10$ & $58 \pm 0.11$ \\
\hline 200 & $70 \pm 0.11$ & $72 \pm 0.10$ & $82 \pm 0.10$ & $39 \pm 0.10$ & $38 \pm 0.11$ & $42 \pm 0.12$ & $82 \pm 0.10$ & $82 \pm 0.10$ & $83 \pm 0.11$ \\
\hline 300 & $100 \pm 0.14$ & $100 \pm 0.13$ & $100 \pm 0.15$ & $70 \pm 0.14$ & $75 \pm 0.14$ & $72 \pm 0.13$ & $92 \pm 0.14$ & $91 \pm 0.14$ & $93 \pm 0.13$ \\
\hline 400 & $100^{\star} \pm 0.21$ & $100 * \pm 0.22$ & $100 * \pm 0.23$ & $100 \pm 0.21$ & $100 \pm 0.20$ & $100 \pm 0.22$ & $100 \star \pm 0.21$ & $100 \star \pm 0.22$ & $100 \star \pm 0.21$ \\
\hline 500 & $100 \star \pm 0.11$ & $100 * \pm 0.12$ & $100 * \pm 0.10$ & $100 \star \pm 0.11$ & $100 * \pm 0.12$ & $100 * \pm 0.10$ & $100 \star \pm 0.12$ & $100 * \pm 0.11$ & $100 * \pm 0.13$ \\
\hline 600 & $100 \star \pm 0.08$ & $100 \star \pm 0.07$ & $100 * \pm 0.09$ & $100 \star \pm 0.07$ & $100 \star \pm 0.06$ & $100 * \pm 0.09$ & $100 \star \pm 0.08$ & $100 * \pm 0.07$ & $100 \star \pm 0.09$ \\
\hline
\end{tabular}

*Fungicidal

Table 4.Fungitoxic spectrum of mixture oil(Lavang and sowa leaf oil in 1:1 ratio) at different concentrations against fungi isolated from stored chickpea seeds

\begin{tabular}{|c|c|c|c|}
\hline \multirow{3}{*}{ Fungal species } & \multicolumn{3}{|c|}{ Per cent inhibition of mycelial growth of isolated fungi (\%) } \\
\hline & $300 \mathrm{ppm}$ & & \\
\hline & & 500ppm & 700ppm \\
\hline Alternaria alternata & $74.1 \pm 0.10$ & $100.3 \pm 0.11$ & $100.0 \pm 0.12$ \\
\hline Aspergillus flavus & $92 \pm 0.14$ & $100 \pm 0.12$ & $100 \pm 0.11$ \\
\hline A. niger & $91 \pm 0.14$ & $100.0 \pm 0.16$ & $100 \pm 0.14$ \\
\hline A. ochraceous & $84.4 \pm 0.13$ & $100.0 \pm 0.13$ & $100.0 \pm 0.12$ \\
\hline A.oryzae & $71.1 \pm 0.23$ & $100.0 \pm 0.16$ & $100.0 \pm 0.18$ \\
\hline A. terreus & $77.7 \pm 0.12$ & $100.0 \pm 0.16$ & $100.0 \pm 0.07$ \\
\hline A. sydowi & $70.1 \pm 0.13$ & $100.0 \pm 0.16$ & $100.0 \pm 0.21$ \\
\hline Chaetomium globosum & $85.1 \pm 0.19$ & $100.0 \pm 0.12$ & $100.0 \pm 0.17$ \\
\hline Colletotrichum dematium & $77.1 \pm 0.10$ & $100.0 \pm 0.12$ & $100.0 \pm 0.13$ \\
\hline Curvularialunata & $74.1 \pm 0.14$ & $100.0 \pm 0.15$ & $100.0 \pm 0.18$ \\
\hline Fusarium moniliforme & $71.0 \pm 0.23$ & $100.0 \pm 0.14$ & $100.0 \pm 0.19$ \\
\hline F. oxysporum & $93 \pm 0.13$ & $100 \pm 0.13$ & $100.0 \pm 0.23$ \\
\hline F. solani & $83.1 \pm 0.13$ & $100.0 \pm 0.15$ & $100.0 \pm 0.16$ \\
\hline Penicillium italicum & $84.4 \pm 0.10$ & $100.0 \pm 0.13$ & $94.3 \pm 0.14$ \\
\hline Rhizopus stolonifer & $74.1 \pm 0.11$ & $100.2 \pm 0.12$ & $100.0 \pm 0.14$ \\
\hline Rhizoctonia solani & $84.1 \pm 0.10$ & $100.0 \pm 0.13$ & $100.0 \pm 0.14$ \\
\hline Sclerotium rolfsii & $87.1 \pm 0.10$ & $100.0 \pm 0.16$ & $100.0 \pm 0.17$ \\
\hline
\end{tabular}

*Values given are mean of three replicates;SD=Standard Deviation

Table 5.Effectof physical factors on the fungitoxicity of mixture oil(Lavang and sowa leaf oil ) 


\begin{tabular}{|ll|}
\hline Applied physical factors & $\begin{array}{l}\text { Per cent inhibition of mycelial (\%) } \\
\text { growth at its MIC }\end{array}$ \\
\hline Autoclaving & $100 \pm 0.19$ \\
$\left(15 \mathrm{lbs} / \mathrm{psi}\right.$ at $\left.120^{\circ} \mathrm{C}\right)$ & \\
For 15 min & \\
\hline Storage time(in days) & \\
25 & $100 \pm 0.11$ \\
50 & $100 \pm 0.13$ \\
75 & $100 \pm 0.14$ \\
100 & $100 \pm 0.22$ \\
125 & $100 \pm 0.21$ \\
150 & $100 \pm 0.23$ \\
\hline
\end{tabular}

Table 6. Physico-chemical characteristics of extracted oil through hydrodistillation

\begin{tabular}{|c|c|c|c|c|c|c|c|}
\hline $\begin{array}{l}\text { Name } \\
\text { of oil }\end{array}$ & $\begin{array}{l}\text { Specific } \\
\text { gravity }\end{array}$ & $\begin{array}{l}\text { Refractive } \\
\text { index }\end{array}$ & $\begin{array}{l}\text { Optical } \\
\text { rotation }\end{array}$ & $\begin{array}{l}\text { Acid } \\
\text { value }\end{array}$ & $\begin{array}{l}\text { Ester } \\
\text { value }\end{array}$ & $\begin{array}{l}\text { Saponification } \\
\text { value }\end{array}$ & Solubility characteristic \\
\hline $\begin{array}{l}\text { Lavang } \\
\text { (bud) oil }\end{array}$ & $\begin{array}{l}1.053 \pm \\
0.0010\end{array}$ & $\begin{array}{l}1.539 \pm \\
0.0013\end{array}$ & $\begin{array}{l}1^{\circ} 64^{\prime} \pm \\
1^{\circ} 10^{\prime}\end{array}$ & $\begin{array}{l}3.941 \pm \\
0.21\end{array}$ & $\begin{array}{l}37.89 \pm \\
0.30\end{array}$ & $41.09 \pm 2.1$ & $\begin{array}{l}\text { Found soluble in } 2 \text { volume of } \\
70 \% \text { alcohol }\end{array}$ \\
\hline $\begin{array}{l}\text { Sowa } \\
\text { leaf oil }\end{array}$ & $\begin{array}{l}0.9233 \pm \\
0.0012\end{array}$ & $\begin{array}{l}1.4606 \pm \\
0.0002\end{array}$ & $+9.342 \pm 2.0$ & $\begin{array}{l}15.64 \pm \\
0.12\end{array}$ & $\begin{array}{l}13.5 \pm \\
0.12\end{array}$ & $182.25 \pm 2.3$ & $\begin{array}{l}\text { Insoluble in water, but miscible in alcohol on } \\
\text { warming }\end{array}$ \\
\hline
\end{tabular}

*Values given are mean of three replicates;SD=Standard Deviation

Table 7. Mycological analysis of 150 days stored chickpea seeds treated with mixture oil(Lavang and sowa leaf oil ) and salphos 


\begin{tabular}{|c|c|c|c|c|}
\hline \multirow[t]{2}{*}{ Fungi recorded } & \multicolumn{2}{|c|}{ Mixture oil } & \multicolumn{2}{|l|}{ Salphos } \\
\hline & US & SS & US & SS \\
\hline Alternaria alternata & - & - & $5.1 \pm 0.07$ & - \\
\hline Aspergillus flavus & - & - & $16.1 \pm 0.04$ & - \\
\hline A. niger & - & - & $17.0 \pm 0.13$ & $4.5 \pm 0.11$ \\
\hline A. ochraceous & - & - & $19.0 \pm 0.21$ & $3.7 \pm 0.04$ \\
\hline A.oryzae & - & - & $9.0 \pm 0.01$ & $4.5 \pm 0.05$ \\
\hline A. terreus & - & - & - & - \\
\hline A. sydowi & - & - & $7.6 \pm 0.12$ & $2.7 \pm 0.08$ \\
\hline Chaetomium globosum & - & - & $14.7 \pm 0.07$ & $1.5 \pm 0.01$ \\
\hline Colletotrichum dematium & - & - & - & - \\
\hline Curvularialunata & - & - & $1.0 \pm 0.24$ & $5.4 \pm 0.07$ \\
\hline Fusarium moniliforme & - & - & - & - \\
\hline F. oxysporum & - & - & $11.3 \pm 0.02$ & $1.0 \pm 0.07$ \\
\hline F. solani & - & - & $8.3 \pm 0.11$ & $0.3 \pm 0.06$ \\
\hline Penicillium italicum & - & - & $7.3 \pm 0.11$ & $1.3 \pm 0.06$ \\
\hline Rhizopus stolonifer & - & - & $5.1 \pm 0.04$ & - \\
\hline Rhizoctonia solani & - & - & $9.0 \pm 0.01$ & $0.5 \pm 0.01$ \\
\hline Sclerotium rolfsii & - & - & $9.3 \pm 0.11$ & $0.7 \pm 0.03$ \\
\hline
\end{tabular}

-:Absence of fungal species;US:Unsterilized seeds; SS:Sterilized seeds

*Values given are mean of three replicates;SD=Standard Deviation

\section{Figures}
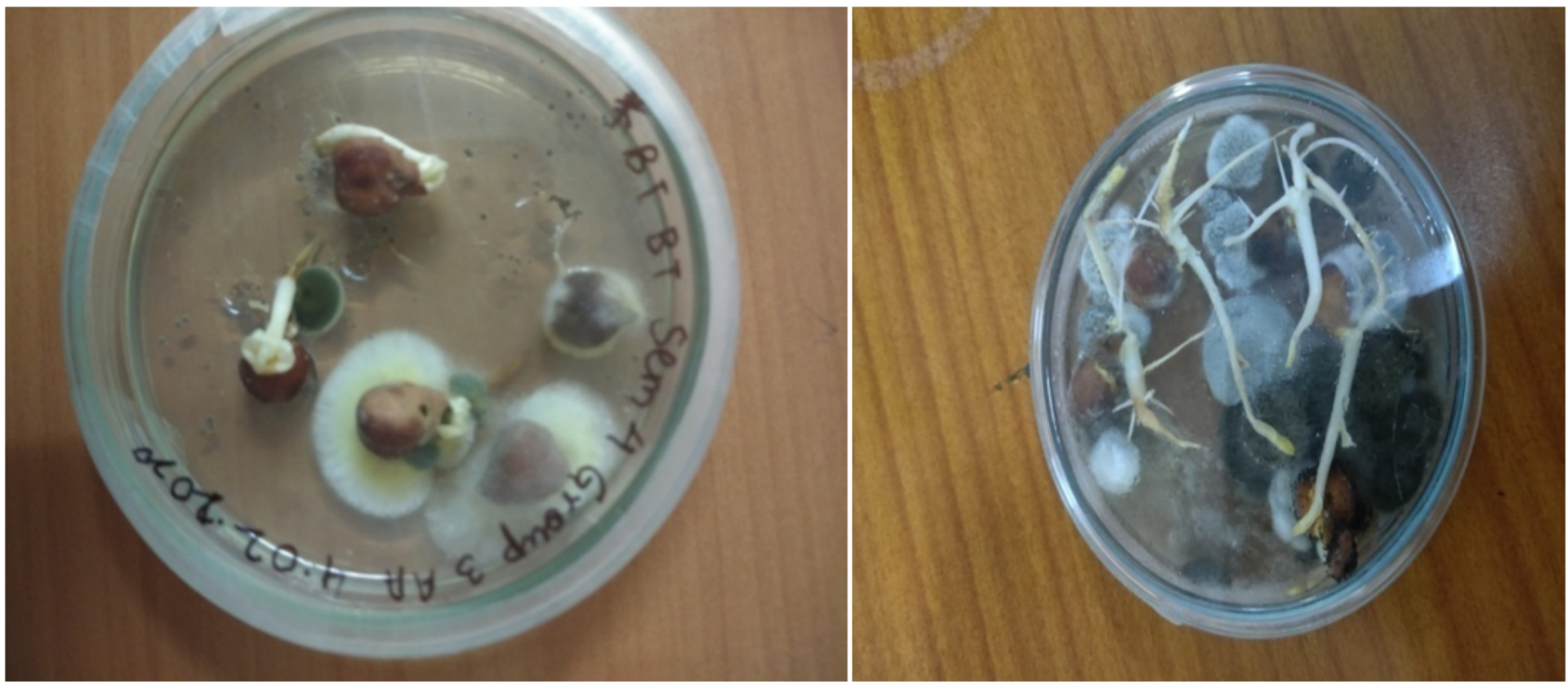
Figure 1

A look at fungi appearing on the chickpea seeds
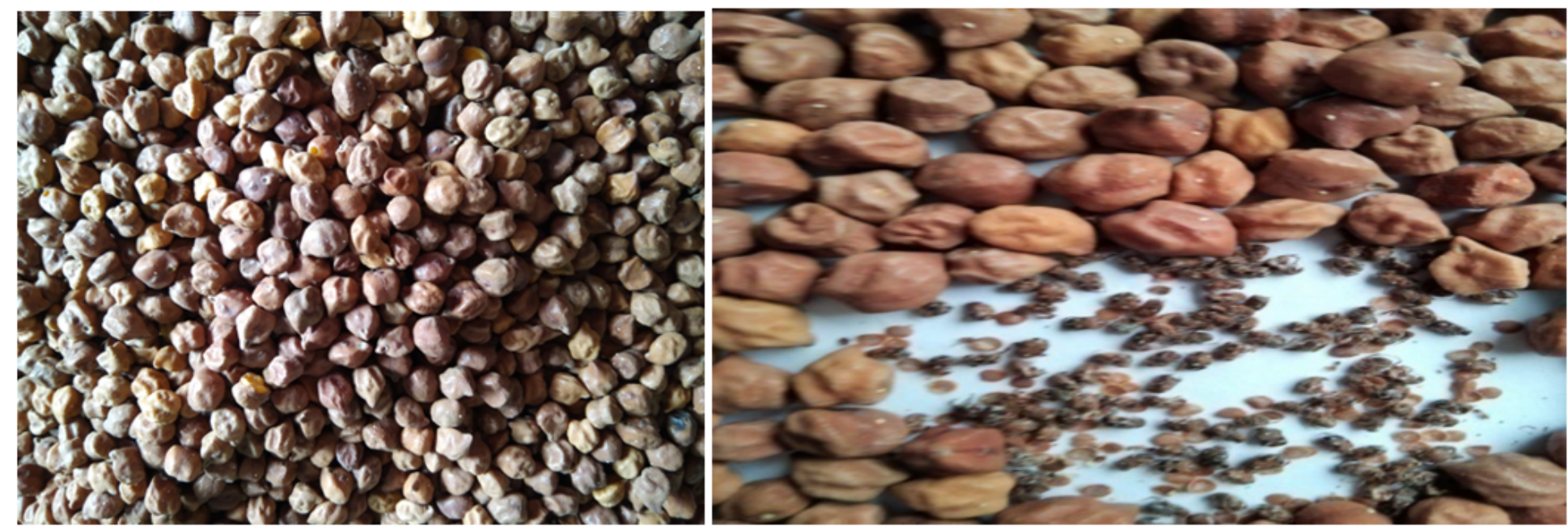

Figure 2

A look on chickpea seed deterioration by insect

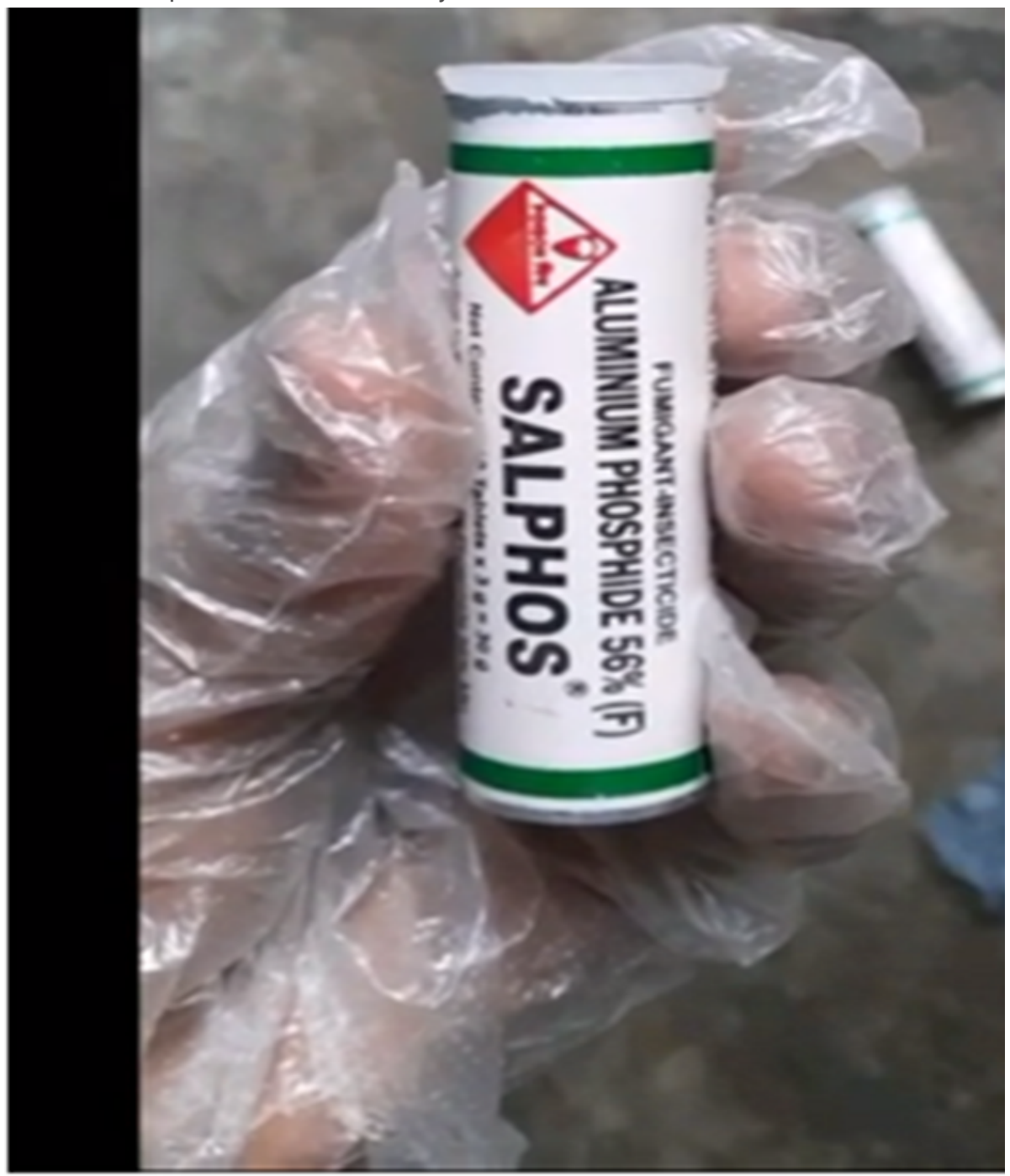

Figure 3 